\title{
Hubungan Aktivitas Fisik dengan Kesegaran Jasmani pada Siswa Sekolah Menengah Pertama Bertaraf Internasional Kota Padang
}

\author{
Hilmainur Syampurma ${ }^{1}$ \\ ${ }^{1}$ Fakultas Ilmu Keolahragaan, Universitas Negeri Padang, Indonesia \\ E-mail: hilmainursyam@fik.unp.ac.id ${ }^{1}$,
}

\begin{abstract}
Abstrak
Rendahnya tingkat kesegaran Jasmani siswa SMP Bertaraf Internasional Kota Padang yang lebih diduga karena dipengaruhi oleh aktivitas fisik. Tujuan penelitian ini untuk mengungkapkan hubungan aktivitas fisik dengan kesegaran jasmani siswa SMP Bertaraf Internasional Kota Padang. Jenis penelitian ini adalah penelitian kuantitatif dengan teknik analisis korelasi. Populasi adalah semua siswa laki-laki SMP Bertaraf Internasional Kota Padang yang berjumlah 448 orang. Sampel penelitian sebanyak 67 orang atau $15 \%$ dari populasi dengan teknik proportional random sampling. Instrumen yang digunakan untuk mengukur Kesegaran Jasmani (Y) adalah Multistage Fitness Test (Tes MFT) dan Aktivitas Fisik (X) dengan Angket. Berdasarkan hasil penelitian dapat disimpulkan bahwa Terdapat hubungan yang signifikan aktivitas fisik dengan kesegaran jasmani, dengan $R_{\text {hit }}(0,51)>R_{\text {tab }}$ $(0,23)$ dan memberikan kontribusi sebesar 26,00\%. Dengan demikian, dapat disimpulkan bahwa untuk meningkatkan kesegaran jasmani siswa SMP Bertaraf Internasional Kota Padang dapat dilakukan dengan peningkatan aktivitas fisik serta memperhatikan faktor-faktor pendukung yang lainnya.
\end{abstract}

Kata Kunci: Aktivitas Fisik, Kesegaran Jasmani,Bertaraf Interasional

\begin{abstract}
Low level of physical freshness of junior high school students in Padang City is more suspected because it is influenced by physical activity. The purpose of this research is to reveal the physical activity relationship with the physical freshness of junior high school students in Padang. This type of research is quantitative research with a correlation analysis technique. The population is all male students of the Padang City International Junior high school amounting to 448 people. Research samples as much as 67 people or $15 \%$ of the population with proportional random sampling technique. The instruments used to measure physical freshness $(Y)$ are Multistage Fitness Test (MFT test) and physical activity $(X)$ with Angket. Based on the results of research can be concluded that there is a significant relationship of physical activity with physical freshness, with a $R_{\text {hit }}(0,51)>R_{\text {tab }}$ $(0,23)$ and the give a contribution of $26.00 \%$. Thus, it can be concluded that to increase the physical freshness of junior high school students in Padang City can be done with increasing physical activity and taking into account other supporting factors.
\end{abstract}

Keywords: Physical activity, physical freshness, international class

\section{PENDAHULUAN}

Sesuai mekanisme yang telah ditetapkan, untuk mewujudkan Sekolah Bertaraf Internasional (SBI) harus dimulai dari tahap rintisan yang disebut Rintisan Sekolah Bertaraf Internasional (RSBI). 
Untuk satuan pendidikan pada jenjang Sekolah Menengah Pertama (SMP) di Kota Padang saat ini, terdapat dua sekolah yang berada dalam tahap rintisan sekolah bertaraf internasional yang disebut SMP Bertaraf Internasional Kota Padang yaitu SMP Negeri 1 di Kecamatan Padang Barat, dan SMP Negeri 8 di Kecamatan Padang Timur. Kondisi ideal atau sesuatu yang harus diwujudkan sebagai Smp Bertaraf Internasional Kota Padang adalah terpenuhinya Indikator Kinerja Kunci Minimal (IKKM) yang berisi delapan unsur Standar Nasional Pendidikan, dan Indikator Kinerja Kunci Tambahan (IKKT) yang berisi berbagai unsur. Salah satu dari delapan unsur Standar Nasional Pendidikan dalam IKKM tersebut adalah Standar Kompetensi Kelulusan Tiap Mata Pelajaran SMP. Salah satu dari seperangkat mata pelajaran tersebut adalah mata pelajaran Pendidikan Jasmani Olahraga dan Kesehatan (Penjasorkes).

Direktorat Pembinaan Sekolah Menengah Pertama (2009:17) menetapkan Standar Kompetensi Kelulusan mata pelajaran Penjasorkes pada SMP Bertaraf Internasional Kota Padang sebagai berikut: (a) mempraktekkan variasi dan kombinasi teknik dasar permainan, olahraga serta atletik dan nilai-nilai yang terkandung di dalamnya; (b) mempraktekkan senam lantai dan irama dengan alat dan tanpa alat; (c) mempraktekkan teknik renang dengan gaya dada, gaya bebas, dan gaya punggung; (dengan) mempraktekkan teknik kebugaran dengan jenis latihan beban menggunakan alat sederhana; (e) mempraktekkan kegiatan-kegiatan di luar kelas seperti melakukan perkemahan, penjelajahan alam sekitar dan piknik; dan (f) memahami budaya hidup sehat dalam kehidupan sehari-hari seperti perawatan tubuh serta lingkungan, mengenal berbagai penyakit dan pencegahannya serta menjauhi narkoba.Berdasarkan Standar Kompetensi Kelulusan mata pelajaran Penjasorkes di atas, dapat dikemukakan bahwa untuk dinyatakan lulus dalam mata pelajaran Penjasorkes, siswa harus memiliki kemampuan mempraktekkan variasi dan kombinasi teknik dasar permainan, olahraga, atletik, senam lantai dan irama, teknik renang, teknik kebugaran, perkemahan, penjelajahan alam sekitar atau piknik, dan menguasai teori kesehatan tentang budaya hidup sehat. Dengan demikian, untuk mencapai kompetensi yang diharapkan, siswa harus melakukan berbagai kegiatan praktek yang melibatkan aktivitas fisik atau jasmani dan mempelajari teori kesehatan. Baik pembelajaran praktek maupun teori kesehatan tersebut sama-sama bertujuan untuk meningkatkan Kebugaran jasmani.

Siswa yang memiliki Kebugaran jasmani yang tinggi akan memiliki kemampuan fisik yang lebih baik untuk melakukan berbagai kegiatan tanpa mengalami kelelahan yang berarti. Untuk mendapatkan Kebugaran jasmani yang tinggi, seseorang harus memiliki kesehatan yang baik. Syafruddin (1992:10) mengemukakan, "Para ahli mengatakan bahwa segar lebih tinggi tingkatannya dari sehat. Orang yang sehat belum tentu segar, dan orang yang segar sudah pasti sehat". Kondisi ideal berupa terwujudnya kesehatan dan Kebugaran jasmani yang tinggi sebagaimana dikemukakan di atas, berbeda dengan realitas yang teramati pada SMP Bertaraf Internasional Kota Padang (SMP Negeri 8 Padang) karena siswa di sekolah ini cenderung kurang memiliki kesehatan yang baik. Lebih jelasnya dapat dilihat pada Tabel 1 berikut:

Tabel 1.Rekapitulasi Data Penyakit yang Dialami Siswa di Sekolah pada SMP Negeri 8

\begin{tabular}{|c|l|r|r|}
\hline No. & \multicolumn{1}{|c|}{ Nama Penyakit } & F & \% \\
\hline 1. & Pusing-pusing & 159 & 36,69 \\
2. & Sakit perut/maag & 97 & 23,60 \\
3. & Demam & 94 & 22,87 \\
4. & Sakit kepala & 23 & 5,60 \\
5. & Penyakit lainnya & 38 & 9,24 \\
\hline \multicolumn{2}{r|}{ Jumlah } & 411 & 100 \\
\hline
\end{tabular}

Sumber: Data Kunjungan Pasien (Siswa) dan Penyakit yang dialami pada Ruang Palang Merah Remaja (PMR) SMP Negeri 8 Padang. 
Tabel 1 di atas menunjukkan bahwa: dari 339 orang siswa SMP Negeri 8 Padang, terjadi 411 kali kunjungan ke ruang PMR karena mengalami sakit di sekolah dengan rincian: 159 atau 38,69\% menderita pusing-pusing, 97 atau 23,60\% menderita sakit perut/maag, 94 atau 22,87\% menderita demam, 23 atau 5,60\% menderita sakit kepala, 38 atau 9,24\% menderita berbagai penyakit lainnya. Dengan demikian tampak bahwa frekuensi sakit yang dialami siswa di sekolah masih cukup tinggi.Data empiris sebagaimana Tabel 1 di atas, dapat dijadikan alasan yang kuat untuk menyatakan kecenderungan rendahnya tingkat Kebugaran jasmani siswa, karena belum memiliki daya tahan atau kekebalan tubuh terhadap serangan penyakit. Hairy dan Ahady (1986:8) antara lain menyatakan bahwa, "Kekebalan terhadap penyakit merupakan salah satu unsur Kebugaran jasmani”.

Berdasarkan permasalahan rendahnya tingkat Kebugaran jasmani siswa SMP Bertaraf Internasional Kota Padang sebagaimana dikemukakan di atas, selanjutnya dilakukan studi pendahuluan dengan membentuk group nominal yang dihadiri oleh 19 orang guru Penjasorkes SMP/MTs di Kota Padang untuk menemukan variabel yang berhubungan dengan Kebugaran jasmani. Menurut Sepriadi dkk "kesegaran jasmani merupakan cermin dari kemampuan fungsi sistem dalam tubuh yang dapat mewujudkan suatu peningkatan kualitas hidup dalam aktivitas fisik. Semakin banyak aktivitas fisik dan olahraga yang di- lakukan seseorang, maka akan semakin baik pula tingkat kesegaran jasmaninya. Melaku- kan aktivitas fisik dan olahraga akan mening- katkan kemampuan tubuh dalam mengkonsumsi oksigen secara maksimal, maka secara otomatis akan berpengaruh terhadap kesegaran jasmani”(Syampurma, dkk,2017).

Aktivitas fisik secara sederhana dapat diartikan sebagai aneka gerakan tubuh yang dihasilkan oleh otot-otot gerak, dan gerak itu membutuhkan pengeluaran energi. Aneka gerakan tubuh atau aktivitas fisik tersebut dilakukan secara spontan dalam berbagai kegiatan sehari-hari, baik kegiatan rutin maupun dalam waktu senggang. Siswa yang memiliki gaya hidup aktif akan lebih banyak melakukan aktivitas fisik karena ia lebih aktif bergerak sehingga memiliki Kebugaran jasmani yang lebih baik. Faktor aktivitas fisik yang diduga berhubungan dengan permasalahan kecenderungan rendahnya tingkat Kebugaran jasmani siswa SMP Bertaraf Internasional Kota Padang sebagaimana diungkapkan di atas, juga diperkuat oleh kenyataan tentang terlalu panjangnya waktu belajar siswa di sekolah. Dengan kata lain, siswa SMP Bertaraf Internasional Kota Padang melaksanakan kegiatan belajar dari pukul 07.00 sampai $15.20 \mathrm{WIB}$ atau lebih kurang 9 jam. Bagi siswa yang ingin mengerjakan Pekerjaan Rumah (PR) dapat memanfaatkan internet sekolah yang dibuka hingga pukul 16.00 WIB. Dikarenakan relatif panjangnya aktivitas siswa di sekolah (pukul 07.00 sampai 15.20/16.00 WIB) tersebut dapat menyebabkan terbatasnya waktu siswa untuk melakukan berbagai aktivitas fisik, seperti berolahraga di sekitar tempat tinggal mereka.

Faktor aktivitas fisik perlu mendapat perhatian dengan cara mengadakan suatu penelitian untuk mengetahui hubungan aktivitas fisik dengan kebugaran jasmani. Tujuan penelitian adalah untuk memamaparkan hubungan aktivitas fisik dengan kebugaran jasmani siswa SMP Bertaraf Internasional Kota Padang. Aktivitas fisik merupakan keaktifan, kegiatan, atau kesibukan seseorang dalam menggunakan aspek fisik atau jasmaninya dalam berbagai kegiatan sehari-hari. Aktivitas fisik dimaksud dengan indikator: aktivitas fisik dalam pembelajaran praktek Penjasorkes di sekolah; aktivitas bermain; dan kegemaran berolahraga.Aktivitas fisik dalam praktek Penjasorkes meliputi keaktifan siswa menggunakan jasmani atau fisiknya untuk mempelajari materi atletik, senam, aktivitas pengembangan (latihan kebugaran jasmani), serta permainan dan olahraga.

Menurut Almatsier (2003)Aktivitas fisik ialah gerakan fisik yang dilakukan oleh otot tubuh dan sistem penunjangnya. Aktivitas fisik adalah setiap gerakan tubuh yang dihasilkan oleh otot rangka yang memerlukan pengeluaran energi. Dengan demikian, dapat diartikan pengertian aktivitas fisik ialah gerakan tubuh oleh otot tubuh dan sistem penunjangnya yang memerlukan pengeluaran energi. Aktivitas fisik yang tidak ada (kurangnya aktivitas fisik) merupakan faktor risiko independen untuk 
Sport Science: Jurnal Sain Olahraga dan Pendidikan Jasmani ISSN 114-562X (Cetak), ISSN XXXX-XXXX(Online)

http://sportscience.ppj.unp.ac.id/index.php/jss/index

penyakit kronis, dan secara keseluruhan diperkirakan menyebabkan kematian secara global (WHO, 2010).

Aktivitas bermain merupakan bagian dari aktivitas fisik. Melalui aktivitas bermain, seseorang anak melakukan berbagai kegiatan spontan di lingkungannya dengan menggunakan imajinasi, penampilan, seluruh perasaan, tangan, dan seluruh badan dengan melibatkan fisik atau jasmaninya. Sementara itu, kegemaran berolahraga diartikan sebagai sikap yang menunjukkan kesukaan yang tinggi untuk melakukan berbagai kegiatan olahraga. Seseorang yang gemar berolahraga akan menunjukkan keaktifan berolahraga, baik secara perorangan maupun bersama-sama dengan orang lain di sekitarnya. Semakin tinggi aktivitas fisik yang dilakukan, melalui pembelajaran praktek Penjasorkes, aktivitas bermain, dan memiliki kegemaran berolahraga yang tinggi di sekitar tempat tinggalnya, jika dilakukan secara teratur akan memberikan efek yang baik untuk peningkatan Kebugaran jasmani. Dengan demikian, diduga terdapat hubungan antara aktivitas fisik dengan Kebugaran jasmani.

\section{METODE}

Penelitian ini tergolong pada jenis penelitian kuantitatif yang menggunakan teknik analisis korelasional, Tempat penelitian (pengambilan data) pada SMP RSBI di Kota Padang yang terdiri dari: SMP Negeri 1 Padang, dan SMP Negeri 8 Padang pengambilan data penelitian ini dilaksanakan pada bulan Maret-April. populasi terjangkau penelitian ini adalah semua siswa lakilaki yang berjumlah 448 orang, teknik penarikan sampel yang digunakan adalah Teknik Proportional Random Sampling, sampel yang ditetapkan dalam penelitian ini adalah sebanyak 67 orang siswa laki-laki atau $15 \%$ dari populasi. Instrumen yang digunakan untuk mengukur Kesegaran Jasmani (Y) adalah Multistage Fitness Test (Tes MFT) dan Aktivitas Fisik (X) dengan Angket .Teknik analisis data dengan teknik analisis korelasional. Khususnya untuk penelitian kualitatif, waktu dan tempat penelitian perlu dituliskan secara jelas (untuk penelitian kuantitatif, juga perlu).Target/subjek penelitian (untuk penelitian kualitatif) atau populasi-sampel (untuk penelitian kuantitatif) perlu diurai dengan jelas dalam bagian ini. Perlu juga dituliskan teknik memperoleh subjek (penelitian kualitatif) dan atau teknik samplingnya (penelitian kuantitatif).

Prosedur Pengumpulan data penelitian ini dilakukan dengan beberapa kegiatan berikut: Mempersiapkan instrumen yang akan digunakan, terdiri dari: (1) instrumen Aktivitas Fisik dengan angket dengan perencanaan kisi-kisi angket, uji coba angket, pelaksanaan pengumpulan data dan verifikasi angket penelitian; dan (2) instrumen Kebugaran Jasmani dengan Tes Lari Multitahap. Menetapkan sumber data, seperti melakukan pendataan terhadap orang coba (sampel) untuk mengetahui apakah mereka telah memenuhi syarat untuk mengikuti tes; dan menyiapkan dokumendokumen yang diperlukan seperti blanko atau formulir tes dan (3).Menentukan personil atau petugas tes yang akan dilibatkan.

\section{HASIL DAN PEMBAHASAN}

\section{Hasil Penelitian}

\section{Kesegaran Jasmani}

Pengumpulan data Kesegaran Jasmani dilakukan dengan tes langsung yaitu Bleep Test atau Lari Multi Tahap kepada 67 orang siswa Sekolah Menengah Pertama Rintisan Sekolah Bertaraf Internasional di Kota Padang yang terpilih jadi sampel. Setelah dilakukan tes, maka diperoleh skor tertinggi 43,9 dan skor terendah 21,4. Skor rata-rata (mean) yang diperoleh 33,15 dan skor baku atau skor standar adalah 5,94. Untuk memudahkan memasukan data ke dalam tabel distribusi dan untuk menentukan klasifikasi skor sampel, maka skor yang diperoleh dibagi menjadi 5 klasifikasi. Dari rumus di atas, maka data dapat dimasukan kedalam tabel distribusi.Untuk lebih jelasnya dapat dilihat pada tabel berikut ini : 
Tabel 2. Distribusi Frekuensi Variabel Kesegaran Jasmani

\begin{tabular}{|c|l|c|c|c|c|}
\hline No & \multicolumn{1}{|c|}{ Klasifikasi } & Skor & $\begin{array}{c}\text { Frekuensi } \\
\text { Absolut }\end{array}$ & $\begin{array}{c}\text { Frekuensi } \\
\text { Relatif (\%) }\end{array}$ & Ket \\
\hline 1 & Baik Sekali & $>42,1$ & 5 & 7,46 & \\
\hline 2 & Baik & $36,2-42,1$ & 19 & 28,36 & \\
\hline 3 & Sedang & $30,3-36,1$ & 17 & 25,37 & \\
\hline 4 & Kurang & $24,2-30,2$ & 21 & 31,34 & \\
\hline 5 & Kurang Sekali & $<24,2$ & 5 & 7,46 & \\
\hline \multicolumn{2}{|c}{$\sum$} & 67 & 100,00 & \\
\hline
\end{tabular}

Dari Tabel 10 di atas diketahui bahwa, dari 67 orang atau $100 \%$ sampel terdapat sebanyak 5 orang siswa atau 7,46\% yang memperoleh skor $>42,1$ atau termasuk dalam klasifikasi baik sekali; 19 orang siswa atau $28,36 \%$ memperoleh skor $36,2-42,1$ atau termasuk dalam klasifikasi baik; 17 orang siswa atau 25,37\% memperoleh skor 30,3 - 36,1 atau termasuk dalam klasifikasi sedang; 21 orang siswa atau 31,34\% memperoleh skor 24,2 - 30,2 atau termasuk dalam klasifikasi kurang; dan 5 orang siswa atau 7,46\% memperoleh skor $<24,2$ atau termasuk dalam klasifikasi kurang sekali.

Dilihat dari perolehan persentase terbanyak, rata-rata dari 67 orang siswa Sekolah Menengah Pertama Rintisan Sekolah Bertaraf Internasional di Kota Padang memiliki Kesegaran Jasmani yang kurang, karena tingkat capaian presentase siswa yang memiliki kesegaran jasmani baik hanya 28,36\%. Berdasarkan distribusi frekuensi tersebut di atas dapat digambarkan dalam grafik berikut:

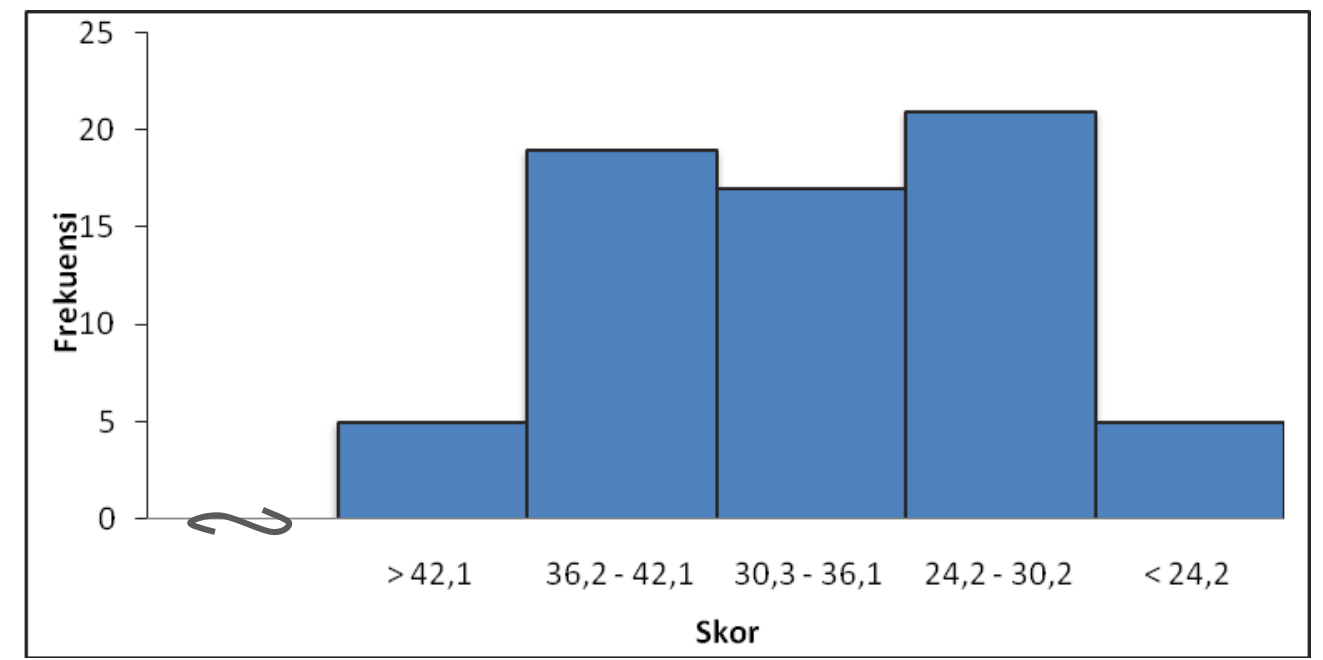

Gambar 1 : Histogram Kesegaran Jasmani Siswa SMP RSBI di Kota Padang

\section{Aktivitas fisik}

Pengumpulan data Aktivitas fisik didapatkan dengan cara menyebarkan angket kepada 67 orang siswa Sekolah Menengah Pertama Rintisan Sekolah Bertaraf Internasional di Kota Padang yang terpilih jadi sampel. Setelah angket disebarkan, maka diperoleh skor tertinggi 282 dan skor terendahnya 185. Skor rata-rata (mean) yang diperoleh 244,44 dan skor baku atau skor standar adalah 22,54. Untuk memudahkan memasukan data ke dalam tabel distribusi dan untuk menentukan bagaimana klasifikasi skor yang diperoleh sampel, maka skor yang dibagi menjadi 5 klasifikasi. Setelah diklasifikasikan, maka data dapat dimasukan kedalam tabel distribusi.Untuk lebih jelasnya dapat dilihat pada tabel berikut ini : 


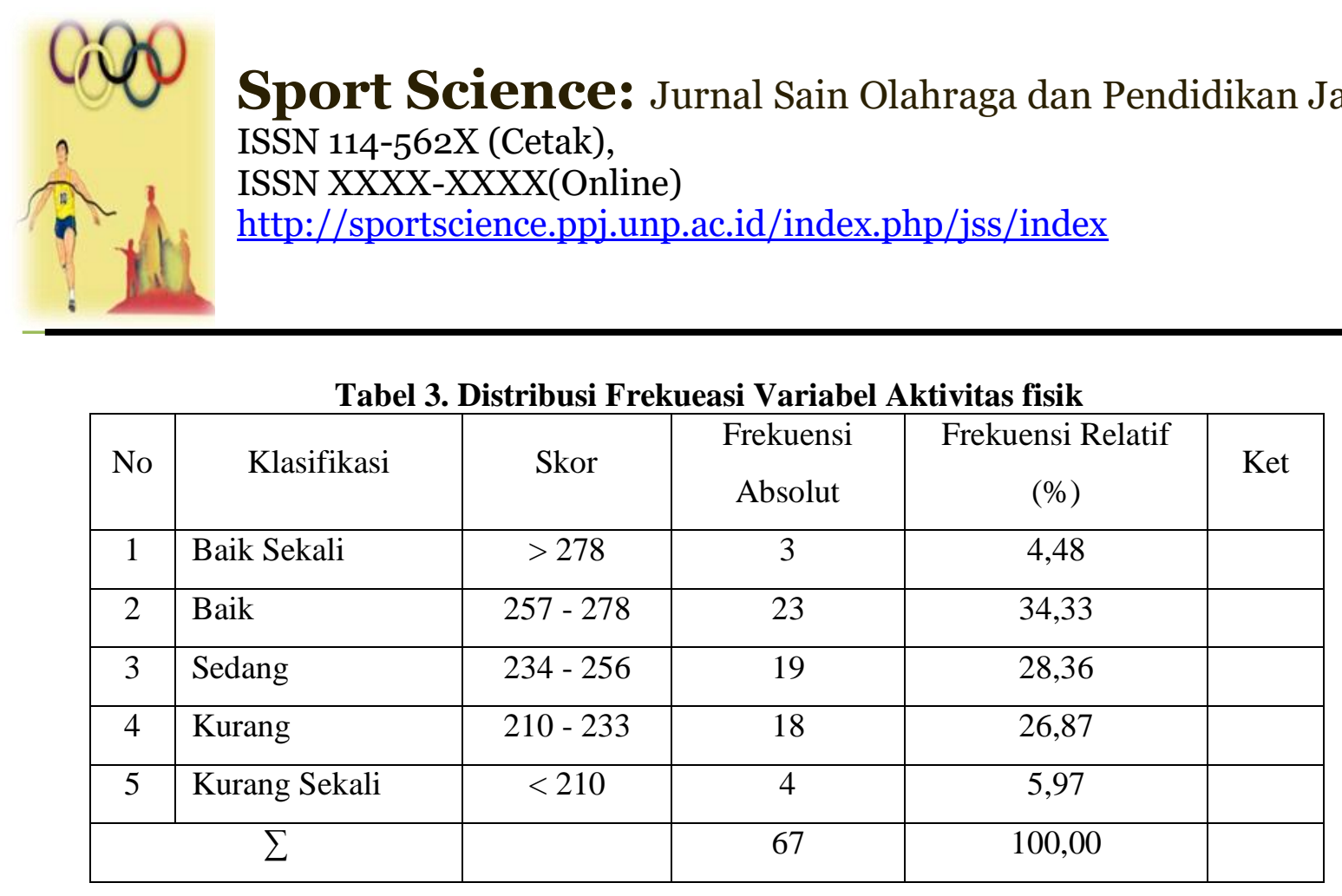

Dari Tabel 12 di atas diketahui bahwa, dari 67 orang atau 100\% sampel sebanyak 3 orang siswa atau 4,48\% yang memperoleh nilai > 278 atau termasuk dalam klasifikasi baik sekali; 23 orang siswa atau 34,33\% yang memperoleh nilai 257 - 278 atau termasuk dalam klasifikasi baik; 19 orang siswa atau 28,36\% memperoleh nilai 234 - 256 atau termasuk dalam klasifikasi sedang; 18 orang siswa atau 26,87\% memperoleh nilai 210 - 233 atau termasuk dalam klasifikasi kurang; dan sebanyak 4 orang siswa atau 5,97\% memperoleh nilai < 210 atau termasuk dalam klasifikasi kurang sekali.

Dilihat dari perolehan persentase terbanyak, rata-rata dari 67 orang siswa Sekolah Menengah Pertama Rintisan Sekolah Bertaraf Internasional di Kota Padang memiliki Aktivitas fisik dalam klasifikasi baik. Hal ini terbukti dari tingkat capaian presentase siswa memiliki Aktivitas fisik baik yaitu 34,33\%. Berdasarkan distribusi frekuensi tersebut di atas dapat digambarkan dalam grafik berikut:

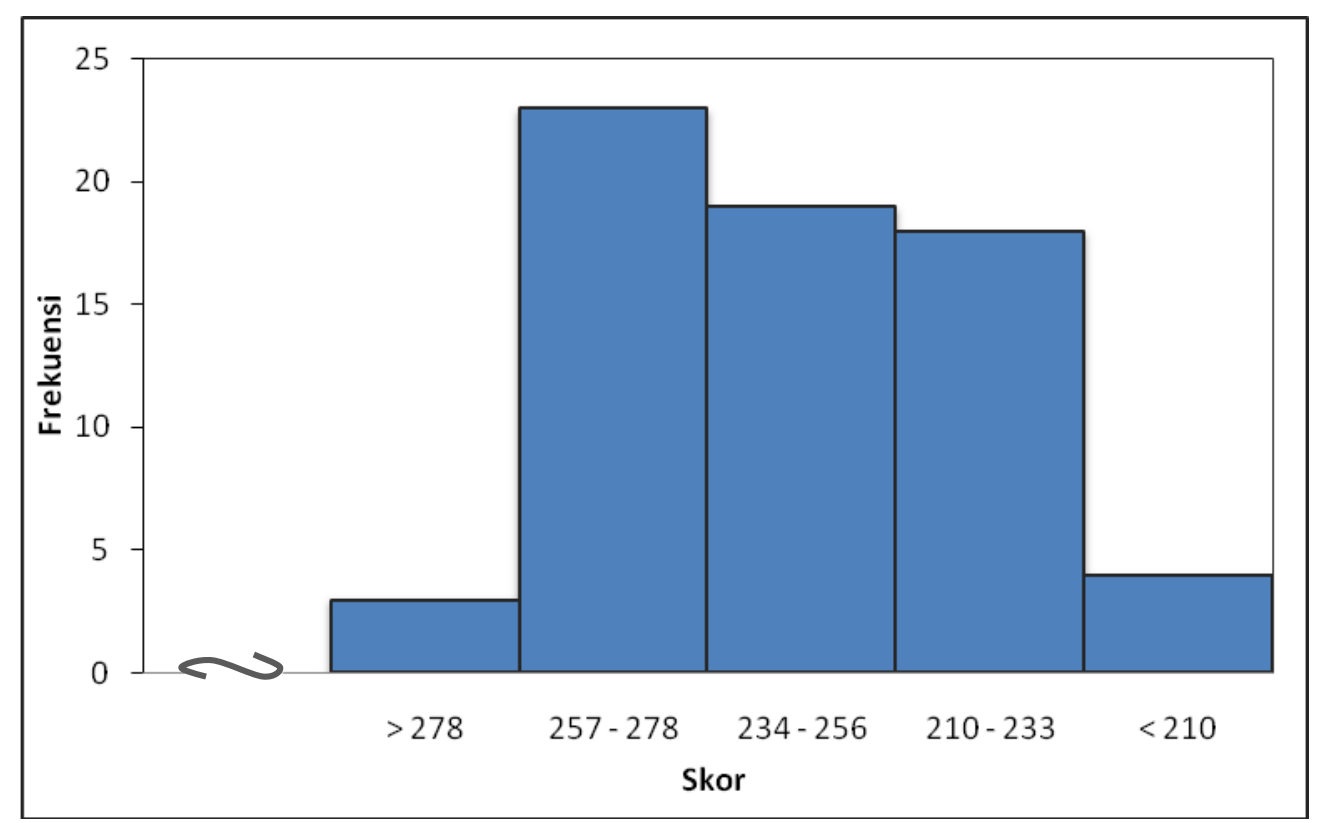

Gambar 2. Histogram Aktivitas fisik Siswa SMP RSBI di Kota Padang 


\section{PEMBAHASAN}

Pengujian hipotesis kedua yaitu terdapat hubungan antara Aktivitas fisik dengan Kesegaran Jasmani siswa Sekolah Menengah Pertama Rintisan Sekolah Bertaraf Internasional (RSBI)Di Kota Padang. Berdasarkan analisis dilakukan, maka didapat rata-rata Kesegaran Jasmani siswa Sekolah Menengah Pertama Rintisan Sekolah Bertaraf Internasional (RSBI) Di Kota Padang sebesar 33,15 dengan simpangan baku 5,94. Untuk skor rata-rata Aktivitas fisik didapat 244,24 dengan simpangan baku 22,54. Dari keterangan di atas diperoleh analisis korelasi antara Aktivitas fisik dan Kesegaran Jasmani, dimana $r_{\text {tab }}$ pada taraf signifikan $\alpha(0,05)=0,51$, berarti $r_{\text {hutung }}(0,51)>r_{\text {tab }}(0,23)$, artinya hipotesis diterima dan terdapat hubungan yang signifikan antara Aktivitas fisik terhadap Kesegaran Jasmani siswa Sekolah Menengah Pertama Rintisan Sekolah Bertaraf Internasional (RSBI) Di Kota Padang.

Dengan $\alpha=0,05$ dan $\mathrm{dk}=\mathrm{n}-2$, diperoleh nilai $\mathrm{t}_{\text {tabel }}=1,67$ yaitu dari $1-\alpha$ atau 0,95 sebagai $\mathrm{dk}$ pembilang dan n-2 (65) sebagai dk penyebut. Kriteria pengujian adalah: jika $t_{\text {hitung }}<t_{\text {tabel }}$ Ho diterima artinyamenyatakan tidak terdapat hubungan antara variabel Ha ditolak. Sebaliknya jika $t_{\text {hitung }}>t_{\text {tabel }} \mathrm{Ha}$ diterima dan Ho ditolak, Oleh karena $t_{\text {hitung }}(4,78)>t_{\text {tabel }}(1,67)$, maka Ho ditolak, dan Ha diterima. Dengan demikian dapat disimpulkan bahwa terdapat hubungan yang signifikan antara variabel bebas dengan variabel terikat. Dengan kata lain terdapat hubungan yang signifikan antara Aktivitas fisik (X2) terhadap Kesegaran Jasmani siswa Sekolah Menengah Pertama Rintisan Sekolah Bertaraf Internasional (RSBI) Di Kota Padang. (Y).

Uji $t_{h} \quad t_{h}=4,78 \quad \longrightarrow \quad t_{\text {tab }}(\alpha=0.05)=1,67$

Jadi $t_{h}>t_{\text {tab }}$, maka Ha diterima (Ho ditolak)

Tabel 4.Analisis Korelasi antara Aktivitas fisik dengan Kesegaran Jasmani

\begin{tabular}{|c|c|c|c|c|c|}
\hline $\mathrm{dk}(\mathrm{n}-2)$ & $\mathrm{r}_{\text {hitung }}$ & $\alpha=0.05$ & $\mathrm{t}_{\text {hitung }}$ & $\alpha=0.05$ & Kesimpulan \\
\hline 65 & 0,51 & 0,23 & 4,78 & 1,67 & Signifikan \\
\hline
\end{tabular}

Koefisien determinasi pada intinya adalah untuk mengukur besar presentase variasi variabel terikat yang dapat dijelaskan oleh variasi variabel bebas. Nilai koefisien determinasi adalah diantara 0 sampai dengan 1, untuk mengetahui berapa presentasenya dapat dilihat dari nilai $R$ square atau $\mathbf{r}_{\text {hitung. }}$.

Berdasarkan hasil perhitungan di atas diketahui bahwa besarnya kontribusi aktifitas fisik terhadap kesegaran jasmani adalah sebesar 0,26 atau $26,00 \%$, sedangkan sisanya sebesar $(100 \%$ $26 \%)=74,00 \%$ dipengaruhi berbagai faktor lainnya. Artinya bahwa aktivitas fisik siswa Sekolah Menengah Pertama Rintisan Sekolah Bertaraf Internasional (RSBI) Di Kota Padang sebagai independent variabel dapat memberikan kontribusi $26,00 \%$, pada dependent variabel yaitu Kesegaran Jasmani siswa Sekolah Menengah Pertama Rintisan Sekolah Bertaraf Internasional (RSBI) Di Kota Padang. Sedangkan sisanya diterangkan oleh variabel lain di luar variabel independent yaitu disebabkan oleh variabel lain. hasil analisis korelasi sederhana antara Aktivitas Fisik sebagai variabel bebas dengan Kesegaran Jasmani sebagai variabel terikat, menunjukkan hubungan yang signifikan dan berkontribusi. Dalam hal ini, Aktivitas Fisik memberikan kontribusi yang cukup besar terhadap KesegaranJasmani, yaitu sebesar $26,00 \%$.

Kontribusi yang cukup besar (26,00\%) yang disumbangkan Aktivitas Fisik terhadap Kesegaran Jasmani tersebut di atas, tampaknya dapat didukung oleh distribusi frekwensi variabel Aktivitas Fisik yang menunjukkan bahwa rata-rata dari 67 sampel siswa SMP RSBI di Kota Padang memiliki Aktivitas Fisik dalam klasifikasi baik. Dengan kata lain, makin tinggi Aktivitas Fisik di kalangan 
Sport Science: Jurnal Sain Olahraga dan Pendidikan Jasmani ISSN 114-562X (Cetak), ISSN XXXX-XXXX(Online)

http://sportscience.ppj.unp.ac.id/index.php/jss/index

siswa SMP RSBI di Kota Padang, makin tinggi tingkat Kesegaran Jasmani yang mereka tunjukkan. Artinya: Aktivitas Fisik memiliki hubungan yang signifikan dengan Kesegaran Jasmani. Hal ini sesuai dengan pendapat Nilawati (2002:35) berikut: Aktivitas fisik adalah setiap gerakan tubuh yang dilakukan oleh otot-otot lurik dan menghasilkan pangeluaran sejumlah energi yang dinyatakan dalam kilo-kalori. Berbagai jenis pekerjaan, kegiatan pada waktu luang, serta aktivitas rutin sehari-hari, termasuk dalam aktivitas fisik. Bila aktivitas fisik dilakukan secara teratur dapat meningkatkan kesehatan.

Berdasarkan kutipan di atas, jelaslah bahwa Aktivitas Fisik seperti: keterlibatan aktif siswa dalam pembelajaran praktek Penjasorkes, mengikuti Kegiatan ekstrakurikuler Panjasorkes, melakukan aktivitas bermain, dan berolahraga di sekitar tempat tinggal yang dilakukan secara teratur akan dapat meningkatkan Kesehatan. Kesehatan itu sendiri menurut Ahady (1986:8) "merupakan salah satu unsur kesegaran jasmani."Mengingat pentingnya Kesegaran Jasmani sebagaimana dikemukakan di atas, dan karena itu perlu dilakukan upaya-upaya peningkatan Aktivitas Fisik. Dengan Kata lain, untuk peningkatan Kesegaran Jasmani yang optimal, dapat dilakukan dengan peningkatan Aktivitas Fisik. Pusat Kasagaran Jasmani dan Rekreasi (1998/1999:18) mengemukakan sebagai berikut: Pembinaan Kesegaran jasmani dapat dilakukan dengan bermacam Kegiatan dan aktivitas fisik antara lain: (1) lari/jogging; (2) jalan cepat; (3) naik sepeda; (4) berenang; (5) latihan senam kesegaran jasmani/aerobik dan senam lainnya yang mudah dilaksanakan serta cocok untuk peserta didik; dan (6) latihan atletik.

Sesuai kutipan di atas, dikemukakan beberapa bentuk Aktivitas Fisik untuk peningkatan Kesegaran Jasmani, yaitu: (1) lari/jogging; (2) jalan cepat; (3) naik sepeda; (4) berenang; (5) latihan senam kesegaran jasmani/aerobik; dan (6) latihan atletik. Dari beberapa Aktivitas Fisik tersebut, terdapat beberapa macam di antaranya telah dilakukan di SMP RSBI Kota Padang, yakni: jogging dan latihan senam kesegaran jasmani/aerobik. Kedua bentuk kegiatan ini dilaksanakan secara rutin setiap hari Sabtu. Untuk masa yang akan datang, beberapa bentuk Aktivitas fisik yang belum dikembangkan ssperti: jalan cepat, naik sepeda, dan atletik juga perlu diadakan sesuai kemarnpuan sarana prasarana yang ada. Oleh karena itu, diperlukan berbagai upaya untuk peningkatan Aktivitas Fisik di kalangan siswa SMP RSBI di Kota Padang, yaitu sabagai berikut:

Pertama: Guru mata palajaran Penjasorkes perlu lebih meningkatkan kualitas pelaksanaan pembalajaran praktek olahraga di lapangan. Dalam hal ini, guru Penjasorkes perlu melakukan hal-hal berikut: (1) Mengawasi agar semua siswa memiliki pakaian olahraga; (2) Mengawasi agar dalam pembelajaran praktek olahraga, semua siswa mengenakan pakaian olahraga; (3) Membiasakan siswa agar hadir di lapangan tepat waktu; (4) Memberikan petunjuk/pengarahan tentang aktivitas yang akan dilaksanakan siswa; (5) Meminta siswa melakukan pemanasan; (6) Mengawasi kegiatan praktek sambil memberikan koreksi-koreksi gerak terhadap siswa; (7) Memotivasi siswa agar melakukan praktek melebihi kemampuan teman atau menciptakan persaingan di antara siswa; (8) Mengakhiri kegiatan praktek pada waktu yang telah ditentukan; dan (9) Melakukan pendinginan badan pada akhir kegiatan praktek.

Kedua: Mengoptimalkan Kegiatan ekstrakurikuler. Kegiatan ekstrakurikuler yang telah dilaksanakan di SMP RSBI Kota Padang adalah latihan pengembangan bakat olahraga yang meliputi: bola voli, basket, dan tenis meja. Guru mata pelajaran Penjasorkes sebagai pengelola kegiatan ekstrakurikuler dalam latihan pengembangan bakat olahraga tersebut, diharapkan benar-benar mengoptimalkan kegiatan yang mereka laksanakan itu. Dalam hal ini diperlukan: (1) Pendataan kembali nama-nama siswa peserta latihan pengembangan bakat olahraga yang meliputi: bola voli, basket, dan tenis meja; (2) Melakukan pengambilan absensi/pengisian daftar hadir sesuai cabang olahraga yang diikuti siswa pada awal dan akhir kegiatan ekstrakurikuler. Pengambilan absensi/pengisian daftar hadir sebanyak dua kali (awal dan akhir). Kegiatan tersebut bertujuan untuk mencegah siswa membolos atau meninggalkan kegiatan; (3) Mengupayakan agar semua siswa, dalam 
melakukan aktivitas fisik atau berolah raga secara optimal; dan (4) Dengan demikian, tentu kegiatan ekstrakurikuler tersebut benar-benar mendorong aktivitas fisik siswa agar lebih aktif bergerak/berolahraga.

Ketiga: Pihak sekolah secara bersama-sama dengan Ketua/Pengurus Komite Sekolah, diharapkan lebih memperhatikan kelengkapan sarana/prasarana olahraga, khususnya untuk pelaksanaan kegiatan ekstrakurikuler tersebut di atas, Dengan kata lain, dibandingkan antara jumlah lapangan bola basket, bola voli, dan tenis meja yang telah ada dengan jumlah siswa peserta ekstrakurikuler, belum memadai. Artinya: jumlah lapangan bola voli, bola basket, dan tenis meja perlu diperbanyak agar semua peserta ekstrakurikuler dapat melakukan aktivitas tanpa harus menunggu giliran terlebih dahulu. Keempat: Orang tua/wali murid dapat membantu memfasilitasi peningkatan Aktivitas Fisik anak/siswa, misalnya dengan cara: (1) Merobah kebiasaan anak dari bermain pasif seperti bermain game online di warung internet menjadi bermain aktif seperti bermain yang melibatkan aktivitas fisik atau jasmani sehingga mengeluarkan keringat; (2) Menyediakan peralatan olahraga/bermain seperti: raket, pakaian olahraga, dan berbagai peralatan olahraga lainnya; dan (3) Mendorong atau memotivasi anak agar mau mengembangkan bakat olahraga yang dimilikinya dengan memberikan dukungan dana, sarana, dan sebagainya.

Selain itu Status Gizi juga akan mempengaruhi kesegaran jasmani. Kenyataannya Status Gizi dan Aktivitas Fisik harus dipadukan secara bersama-sama. Dengan kata lain, di samping pemberian Status Gizi yang baik, harus dibarengi dengan Aktivitas Fisik yang dilakukan secara teratur. Bahan makanan atau zat-zat gizi yang kita konsumsi, jika tidak digunakan sebagai energi untuk melakukan Aktivitas Fisik, maka akan tersimpan pada tempat tertentu. Penumpukan bahan makanan "berupa zat lemak yang berlebihan di dalam tubuh akan menyebabkan kegemukan (obesitas) sehingga akan mengganggu sistem peredaran darah. Wahyuri (2010:27) mengemukakan sebagai berikut: Agar bahan makanan yang berupa lemak tidak menumpuk, harus digunakan untuk manjadi energi pada saat melakukan aktivitas fisik. Dengan aktivitas fisik yang teratur, maka tidak akan terjadi penumpukan lemak sehingga seseorang bisa terhindar dari resiko menderita penyakit yang berkaitan dengan sistem peredaran darah. Pendapat di atas, pada intinya menyatakan bahwa zat gizi harus dikeluarkan atau digunakan sebagai sumber energi untuk melakukan berbagai aktivitas fisik. Seseorang yang malakukan Aktivitas Fisik secara teratur akan membakar zat-zat lemak sebagai sumber energi, sehingga tidak terjadi penumpukan di dalam tubuh. Dengan demikian akan terhindar dari kegemukakan atau obesitas.

\section{KESIMPULAN}

Terdapat hubungan yang signifikan antara Aktivitas Fisik dengan Kesegaran Jasmani, yakni dengan nilai $\mathrm{R}_{\text {hit }}(0,51)>\mathrm{R}_{\mathrm{tab}}(0,23)$ dan berkontribusi sebesar $26,00 \%$. Artinya: semakin baik Aktivitas Fisik seseorang, maka semakin besar pula kontribusinya untuk peningkatan Kesegaran Jasmani. Aktivitas Fisik merupakan keaktifan seseorang dalam menggunakan fisik, badan atau jasmani untuk bergerak dengan mengeluarkan sejumlah kalori, seperti berolahraga dan bermain. Makin tinggi Aktivitas Fisik yang dilakukan seseorang, maka makin tinggi pula tingkat Kesegaran Jasmani yang dimilikinya. Dilihat dari Histogram Aktivitas Fisik Siswa SMP RSBI di Kota Padang (Gambar 4) bahwa: 4,48\% siswa dalam klasifikasi Baik Sekali; 34,33\% dalam klasifikasi Baik; 28,36\% dalam klasifikasi Sedang; 26,87\% dalam klasifikasi Kurang; dan 5,97\% dalam klasifikasi Kurang Sekali. Walaupun dilihat dari rata-rata persentase terbanyak, Aktivitas Fisik siswa berada dalam klasifikasi Baik (54,55\%), namun masih banyak yang berada dalam klasifikasi Sedang, Kurang, dan Kurang Sekali. 
Sport Science: Jurnal Sain Olahraga dan Pendidikan Jasmani ISSN 114-562X (Cetak), ISSN XXXX-XXXX(Online)

http://sportscience.ppj.unp.ac.id/index.php/jss/index

\section{DAFTAR RUJUKAN}

Adisapoetra, Iskandar Z., dkk. 1999. "Panduan Teknis Tes dan Latihan Kebugaran Jasmani untuk Anak Usia Sekolah". Makalah Seminar dan Widiakarya Nasional Olahraga dan Kebugaran Jasmani, Jakarta: 6-7 September.

Arikunto, Suharsimi. 2006. Prosedur Penelitian Suatu Pendekatan Praktik. Jakarta: Rineka Cipta.

Andri Darus Sholihi, Sugiarto ANALISIS AKTIVITAS FISIK DAN AKTIVITAS BELAJAR PADAMAHASISWA FAKULTAS ILMU KEOLAHRAGAAN UNIVERSITAS NEGERI SEMARANG DALAM MEMANFAATKAN WAKTU LUANG unnes.ac.id J SSF 4 (4): Semarang, Indonesia (2015).

BSNP dan Pusat Kurikulum. 2006. Panduan Pengembangan Diri untuk Satuan Pendidikan Dasar dan Menengah. Jakarta.

de Vries, Herbert A. and Terry J. Housch. 1994. Physiology of Exercise for Physical Education, Athletic and Exercise Science. Dubuque: WBC. Brown \& Bench Mark Publishers.

Direktorat Jenderal Olahraga. 2000. Seleksi dan Penelusuran Minat dan Bakat Olahraga. Jakarta: Depdiknas.

Echols, John M., dan Hassan Shadily. 1998. Kamus Inggris-Indonesia An English-Indonesian Dictionary. Jakarta: PT. Gramedia.

Gusril. 2004. "Beberapa Faktor yang Berkaitan dengan Kemampuan Motorik Siswa Sekolah Dasar Negeri Kota Padang". Disertasi tidak diterbitkan. Jakarta: Program Pascasarjana Universitas Negeri Padang.

Lutan, Rusli. 2001. Pendidikan Kebugaran Jasmani Orientasi Pembinaan di Sepanjang Hayat. Jakarta: Depdiknas.

Pusat Kebugaran Jasmani dan Rekreasi. 1997. Petunjuk Pelaksanaan Pola Umum Pembinaan dan Pengembangan Kebugaran Jasmani. Jakarta: Departemen Pendidikan dan Kebudayaan.

Pusat Pengembangan Kualitas Jasmani. 2000. Pedoman dan Modul Pelatihan Kesehatan Olahraga bagi Pelatih, Olahragawan, dan Pelajar. Jakarta: Depdiknas.

Syampurma, Hilmainur. dkk. 2017.Perbedaan Tingkat Kesegaran Jasmani Berdasarkan Status Gizi. Jurnal Media Ilmu Ke olahragaan Indonesia. Volume 7. Nomor $1: 2829$

Sajoto, Mochamad. 1988. Pembinaan Kondisi Fisik dalam Olahraga. Jakarta: Proyek Pengembangan Lembaga Pendidikan Tenaga Kependidikan.

Sudarno. 1992. Pendidikan Kebugaran Jasmani. Jakarta: Direktorat Jenderal Pendidikan Tinggi Proyek Pembinaan Polis: Bulgess Publishing Company.

Syafruddin (1992). Pengantar Ilmu Melatih. FPOK IKIP. Padang.

Sugioyono.2007. Statistika Untuk Penelitian.Bandung:Alfabeta. 

ISSN 114-562X (Cetak),

Undand-undang Republik Indonesia Nomor 20 Tahun 2004 Tentang Sistem Pendidikan Nasional. 2003. Jakarta: Diperbanyak oleh BP. Cipta Jaya.

Wahjoedi. 2001. Landasan Evaluasi Pendidikan Jasmani. Jakarta: PT. Radja Grafindo Persada.

Yusuf, A. Muri. 2005. Metodologi Penelitian Dasar-Dasar Penyelidikan dan Ilmiah. Padang: UNP Press. 